\title{
УAK 159.4
}

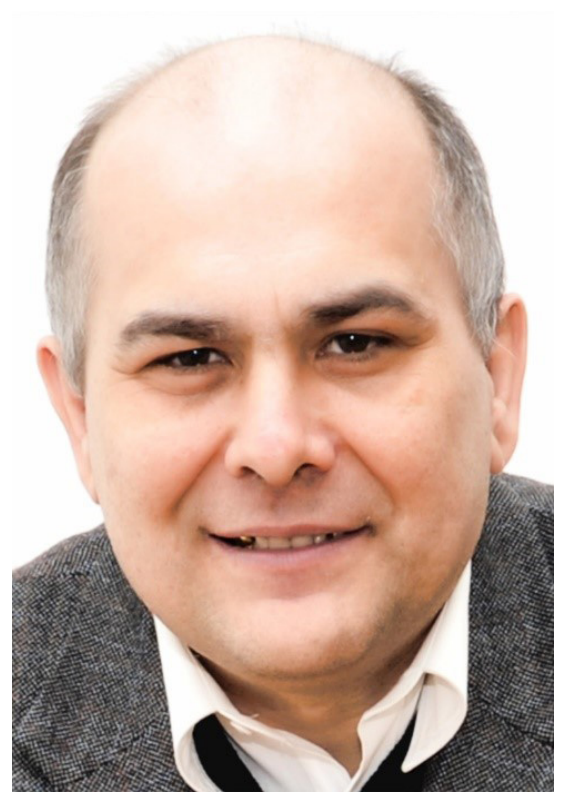

\section{Тесленко}

\section{Александр Николаевич}

Кокшетауский университет

им. А. Мырзахметова

(Кокшетау, Казахстан)

teslan@rambler.ru

ORCID: 0000-0003-1398-1832

\section{Alexander N. Teslenko}

Kokshetau University named

after A. Myrzakhmetov

(Kokshetau, Kazakhstan)

teslan@rambler.ru

ORCID: 0000-0003-1398-1832

\section{Мигранты в большом городе: криминологический аспект}

\begin{abstract}
Аннотация
В статье рассмотрены криминологические аспекты миграционных процессов в столице Казахстана, одном из крупнейших мегаполисов страны - городе Нур-Султан. Анализируются особенности конфликтологического потенциала столичного социума в контексте миграционной преступности. Выявлены тревожности в столичном социуме, связанные с миграционным потоком, характерные криминологические показатели миграционной преступности. Предлагается описание миграционной преступности в терминологии «общества рисков» У. Бека. Систему предупреждения миграционной преступности предлагается строить на минимизации этих рисков.

\section{Migrants and Metropolis: Criminological Aspect}

\section{Abstract}

The article examines criminological aspects of migration processes undergoing in the capital of Kazakhstan, Nur-Sultan. The features of conflictological opportunities among citizens of Nur-Sultan in the context of immigration and crime are analyzed. The study revealed social anxiety associated with the flow of migrantsas well assome criminological features of immigration crime. The article offers a description of immigration crime based onBeck's theory of the "risk society". Riskminimization should become the core of the immigration crime prevention system.
\end{abstract}

\section{Киючевые слова}

урбанизация, мегаполис, миграция, иммиграция, мигранты (внешние/внутренние), риски миграции, миграционная преступность, миграционная политика

\section{Keywords}

urbanization, metropolis, migration, immigration, migrants (external/internal), migration risks, immigration crime, migration policy

Для цитирования: Тесленко, А. Н. (2021). Мигранты в большом городе: криминологический аспект. Российский девиантологчческий журнал, 1(2), 326-334. DOI: 10.35750/2713-0622-2021-2-326-334. 


\section{Scientific article}

For citation: Teslenko, A. N. (2021). Migrants and Metropolis: Criminological Aspect. Russian Journal of Deviant Behavior, 1(2), 326-334. DOI: 10.35750/2713-0622-2021-2-326-334.

\section{Введение}

Урбанизация - закономерный тренд в современном мире. Сегодня более половины населения мира проживает в городах, а к 2050 году численность горожан достигнет почти 70\% населения мира (Щербакова, 2018). Практика урбанизации и глобализации убеждает нас в том, что любой мегаполис - это своеобразный «магнит» для внешней и внутренней миграции. Одновременно в процессе развития столь сложного социального организма как мегаполис возникают разнообразные противоречия, которые часто переходят в форму острого конфликта. Зачастую подобного рода конфликты вызывают противоречия между интересами личности и общественными интересами, вследствие чего совершается правонарушение или преступление.

Именно в больших городах концентрируется крупная промышленность и сфера услуг, которые являются базовыми для национальной экономики в целом. Необходимость в рабочих ресурсах требует привлечения дополнительной рабочей силы, прежде всего за счет привлечения мигрантов.

В середине XX века Джон Кеннеди назвал США нацией мигрантов (Kennedy, 1964). Тоже самое можно сказать и о Казахстане. Согласно оценкам экспертов $\mathrm{OOH}$, Казахстан позиционируется как 15-е государство среди 30 стран мира с наибольшим числом международных мигрантов: лидирующие первые три позиции занимают США, Россия, Германия. По удельному весу международных мигрантов среди 30-стран мира Казахстан занимает 16-е место с 19,5 \% международных мигрантов от всего населения (Щербакова, 2018). Но если Российская Федерация в основном привлекает внешних мигрантов, то в Казахстане беспрецедентный уровень внутренней миграции. Так, за период 19912008 годов 4,7 миллиона казахстанцев стали переселенцами в пределах страны. За эти же годы во внешней миграции (эмиграции + иммиграции) участвовали 4,5 миллиона казахстанцев, т.е. объем внутренней миграции чуть превышает внешний в постсоветский период (Демографический сборник, 2020).

За четверть века столица Казахстана Нур-Султан стала центром притяжения внутренних мигрантов, а также одним из промежуточных звеньев транснациональных каналов внешней миграции. Этому способствует не только географическое положение столицы как важной транспортной развязки, но и стабильность социально-политической обстановки и экономическая привлекательность столицы.

Согласно данным Комитета по статистике Министерства национальной экономики Республики Казах- стан, население столицы постоянно растет. Так, с 1992 года число жителей возросло в 3,6 раза - с 298700 до 1078400 человек на начало 2020 года, соответственно, доля населения Нур-Султана в общей численности населения Казахстана увеличилась с 1,8 до 5,9 \% (Демографический сборник, 2020). Всего с января по ноябрь 2020 года в Нур-Султане число жителей выросло на 39,96 тыс. человек (Демографический сборник, 2020). Это порождает потребность в рассмотрении и изучении миграционных процессов комплексными методиками, в том числе в рамках мониторинга межэтнической ситуации. Цель данной статьи - изучение состояния, динамики и факторов влияния миграционных процессов на межэтническую ситуацию в мегаполисе для выработки практических рекомендаций по повышению эффективности реализации государственной политики в сфере общественного согласия и общенационального единства в столице Казахстана.

\section{Методология, методы и материалы исследования}

Социологическое исследование в рамках проекта «Мониторинг межэтнической ситуации в городе Нур-Султан» проводилось в 2021 году ежеквартально на выборочной совокупности не менее 1000 респондентов (4000 - годовой объем респондентов). Модель выборки - смешанная: 1-й этап - распределение административных единиц; серийная (гнездовая) выборка. 2-й этап - квотная выборка по полу, возрасту, этнической принадлежности. Сбор первичной социологической информации осуществлялся методом комбинированного очного опроса (по месту жительства, учебы, работы, иного массового скопления респондентов разных социально-профессиональных и демографических групп, отвечающих задачам исследования). В статье используются материалы первого (март-апрель 2021 г.) и второго (июнь-июль 2021 г.) срезов.

Исследовательская группа в ходе мониторинга сформулировала несколько исследовательских вопросов, касающихся влияния миграционных процессов на состояние межэтнической ситуации в столице:

1. Как жители столицы оценивают миграционные потоки в столицу?

2. Что привлекает в столицу все новые и новые потоки внутренних мигрантов?

3. Как респонденты оценивают масштаб миграции в столицу с целью поиска постоянного места жительства за последние 5 лет?

4. Какие группы мигрантов вызывают у жителей столицы наибольшие опасения и тревоги? 
5. Насколько важны мигранты для дальнейшего развития столицы?

\section{Результаты исследования}

Миграция населения - передвижение людей (мигрантов) через границы территорий (страны, региона, области, района), связанное с переменой места жительства - является не только одной из составных частей демографической статистики страны, но и важнейшим триггером состояния межэтнических отношений. Нур-Султан является центром притяжения внутренних мигрантов, а также одним из промежуточных звеньев транснациональных каналов внешней миграции. Этому способствует не только географическое положение столицы как важной транспортной развязки, но и стабильность социально-политической обстановки и экономическая привлекательность столицы.

Отвечая на вопрос «Как Вы оцениваете миграционные потоки в столицу?», большинство респондентов видят в этом положительные (46 \%) и скорее положительные (14 \%) черты (диаграмма 1). Эти данные коррелируются с эмпирическими данными, показывающими, что основной контингент жителей столицы сформировался за последние 20-30 лет: 16 \% респондентов живут в столице менее 20 лет и только $13 \%$ - уже более 20 лет. Но доминирующей группой
А. Н. Тесленко

в ходе второго среза стали респонденты, временно проживающие в столице (36 \%), к ним можно причислить и живущих на окраинах города или за его пределами (16\%).

С точки зрения респондентов, столица и дальше будет привлекать новые потоки внутренних мигрантов (табл. 1). В рейтинге миграционных факторов доминирует фактор качества жизни и экономической стабильности (47 \%). Качество жизни определяется социологами и экономистами как обозначение определенных условий и характеристик жизни человека, основанных на его собственной степени удовлетворенности этими условиями и характеристиками. Оно также включает в себя такие объективные и субъективные факторы, как состояние здоровья, ожидаемая продолжительность жизни, условия окружающей среды, питание, бытовой комфорт, социальное окружение, удовлетворение культурных и духовных потребностей, психологический комфорт и др.

Столица, безусловно, предоставляет мигранту при желании более высокий уровень доступности и качества образования. Согласны с этим утверждением 35 \% опрошенных. В профессиональном плане столица открывает прекрасные перспективы для карьерного роста $(42 \%)$ и развития собственного бизнеса (43\%). Наконец, 29 \% опрошенных учитывают уникальное геополитическое расположение столицы Казахстана (29\%).

Аиаграмма 1. Как Вы оцениваете миграционные потоки в столицу?

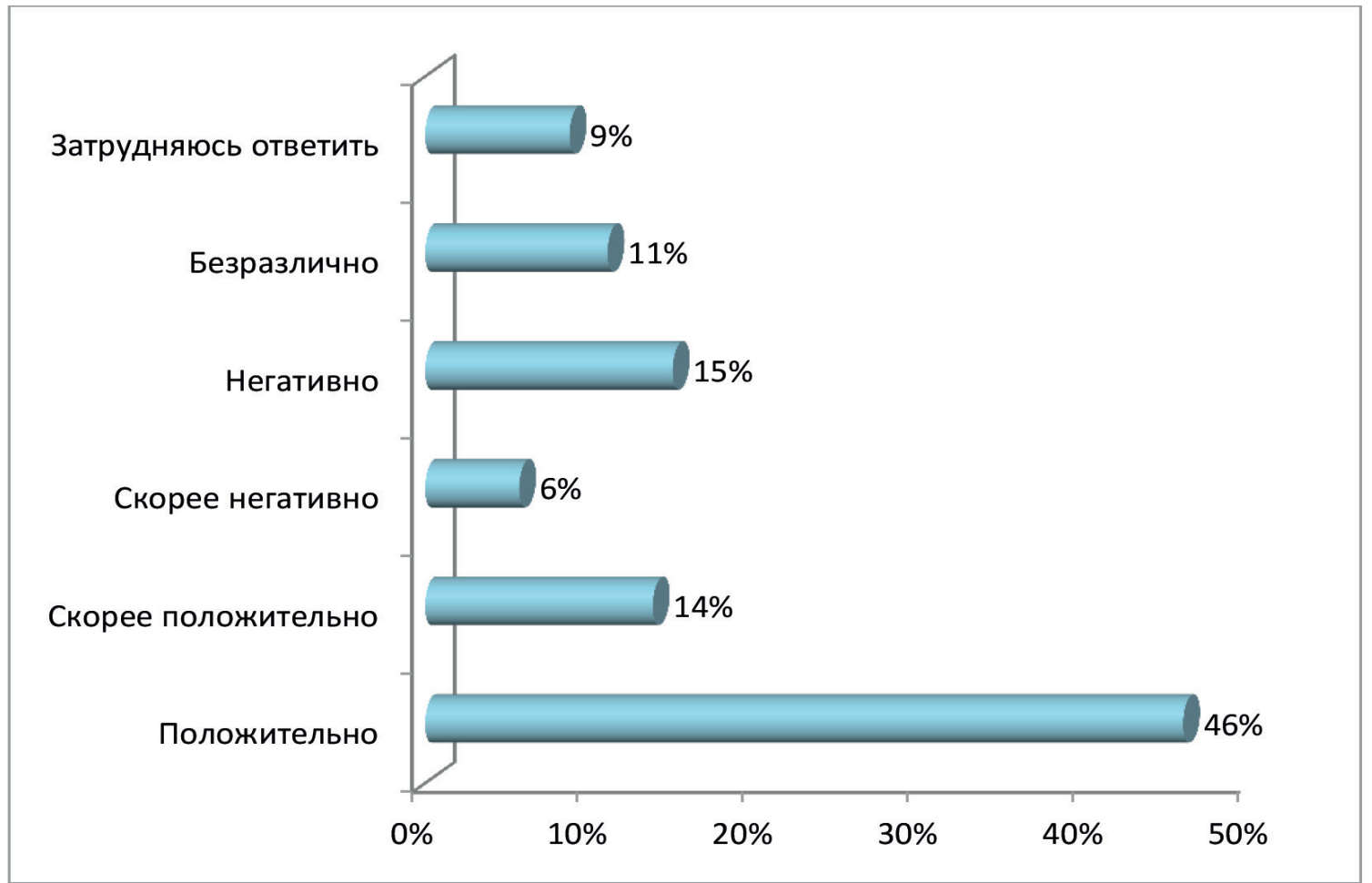




\section{Российский девиантологический журнал}

Alexander N. Teslenko

Таблица 1. На Ваш взгяяА, что привлекает в столицу новые потоки внутренних мигрантов?

\begin{tabular}{|c|c|c|c|c|c|}
\hline & $\begin{array}{c}\text { Качество жизни } \\
\text { и экономическая } \\
\text { стабильность }\end{array}$ & $\begin{array}{c}\text { Доступность } \\
\text { и качество } \\
\text { образования }\end{array}$ & $\begin{array}{c}\text { Перспективы } \\
\text { карьерного } \\
\text { роста }\end{array}$ & $\begin{array}{c}\text { Благоприятные } \\
\text { условия для } \\
\text { ведения бизнеса }\end{array}$ & $\begin{array}{c}\text { Геополитическое } \\
\text { расположение }\end{array}$ \\
\hline Согласен & $47 \%$ & $35 \%$ & $42 \%$ & $43 \%$ & $29 \%$ \\
\hline Скорее согласен & $24 \%$ & $23 \%$ & $22 \%$ & $20 \%$ & $18 \%$ \\
\hline $\begin{array}{c}\text { Скорее } \\
\text { не согласен }\end{array}$ & $7 \%$ & $10 \%$ & $7 \%$ & $10 \%$ & $12 \%$ \\
\hline $\begin{array}{c}\text { Не согласен } \\
\text { Затрудняюсь } \\
\text { ответить }\end{array}$ & $8 \%$ & $13 \%$ & $11 \%$ & $19 \%$ & $28 \%$ \\
\hline
\end{tabular}

Оценивая масштаб миграции в столицу с целью поиска постоянного места жительства за последние 5 лет, респонденты в целом разошлись во мнениях (диаграмма 2). Более половины опрошенных (по сумме вариантов «очень большой» $(34 \%)$ и «скорее большой» $(24 \%)$ считают масштаб миграции в столицу достаточно вы- соким. В тоже время около $20 \%$ опрошенных с этим не согласны: «небольшой» (13\%), «скорее небольшой» (13\%). Интересно, что $14 \%$ опрошенных затруднились ответить на этот вопрос, что можно интерпретировать как желание скрыть свое раздражение мигрантами и истинное мнение о данной проблеме.

Аиаграмма 2. Как бы Вы оценили масштаб миграции в столицу с целью поиска постоянного места жительства за последние 5 лет?

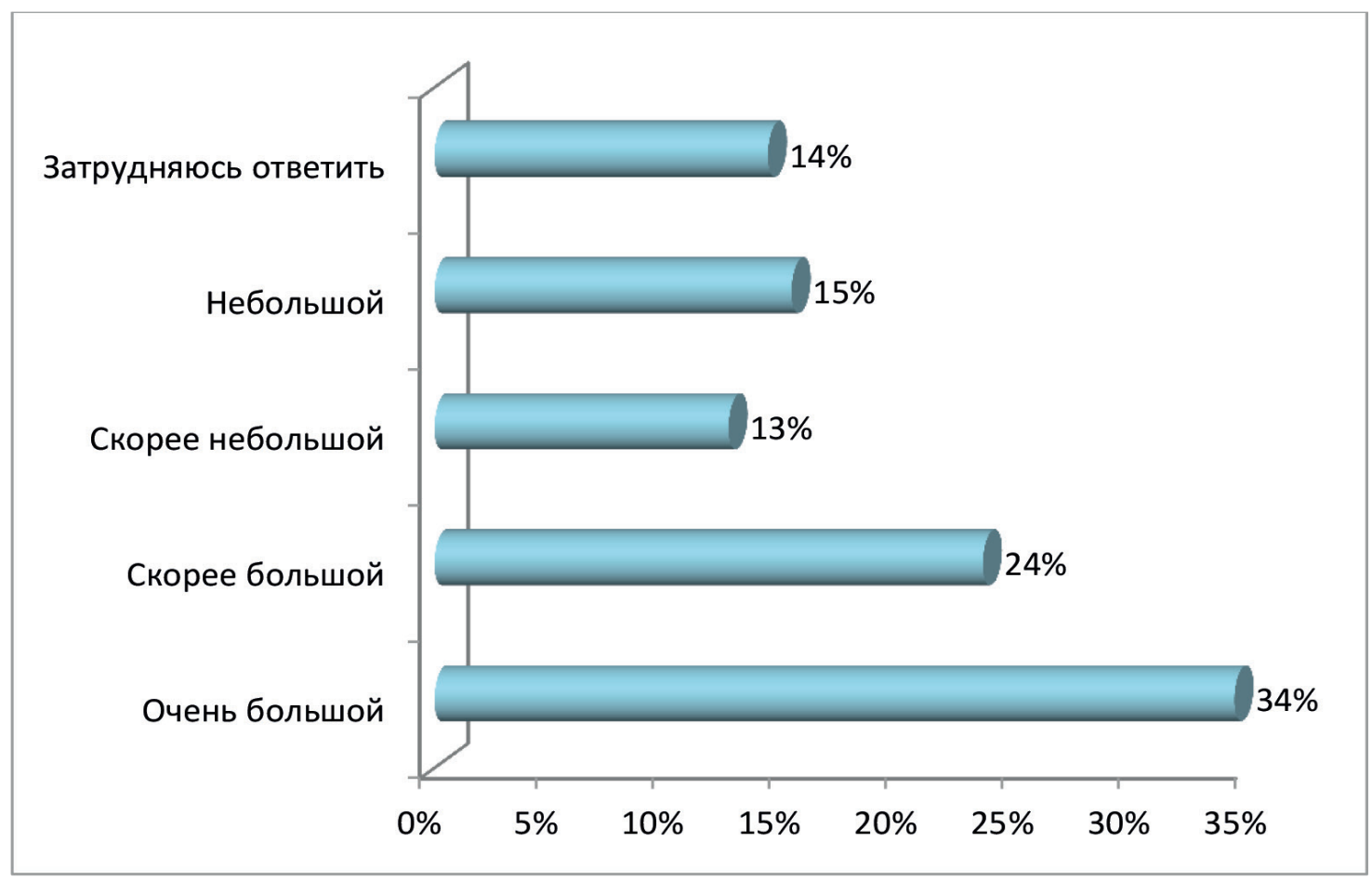


При этом наибольшие опасения и тревоги вызывают у респондентов трудовые мигранты из стран дальнего зарубежья, таких как Китай, Афганистан и др. (27 \%) и стран ближнего зарубежья, прежде всего из соседних стран Центральной Азии
(19 \%). Столичный рынок труда, столь привлекательный для нелегальных мигрантов и работодателей, по мнению столичных жителей, провоцирует определенный уровень ксенофобии к иностранцам (диаграмма 3).

Аиаграмма 3. Какие группы мигрантов вызывают у Вас наибольшие опасения и тревоги?

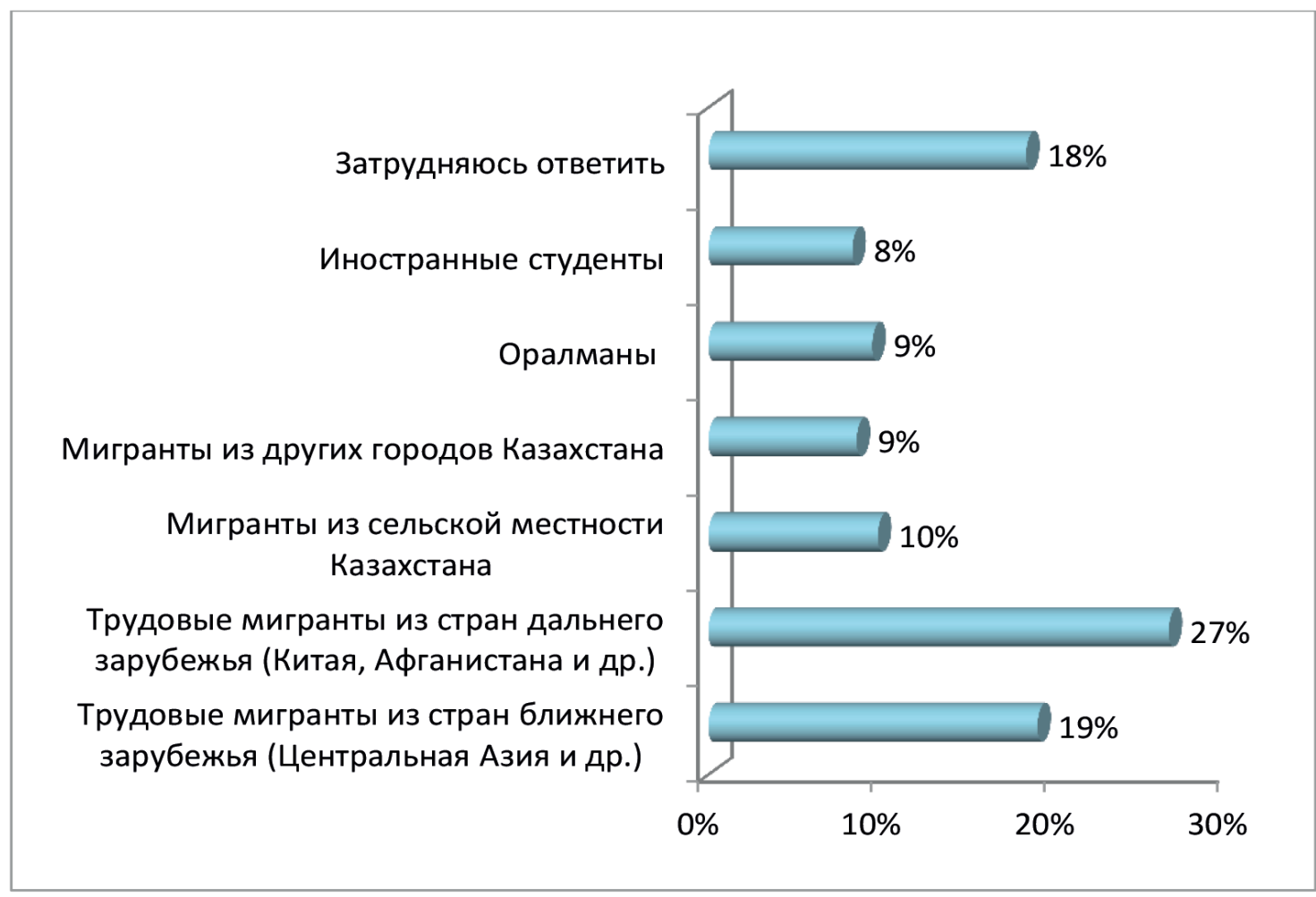

Миграция из других городов и сельской местности Казахстана представлена минимальными данными (в совокупности 19 \%). Именно они составляют серьезную конкуренцию коренному населению столицы на рынке труда. Мировой опыт показывает, что хуже образованные, плохо подготовленные в культурно-психологическом отношении к жизни в большом городе, они становятся маргинальной группой и вносят элемент общей нестабильности в столичный социум (Killias \& Lukash, 2019).

Особое место в структуре миграционных потоков занимают оралманы, многие из которых так и не интегрировались в современное казахстанское общество. Показатели негативного отношения к этой группе (9\%) скрываются в их большей традиционности в отличие от местных казахов и низким уровнем адаптации к урбанистической культуре мегаполиса.

Безусловно, оценка отношения к мигрантам носит эмоциональный характер и раскрывается в трех диахронических парах: «доброжелательно - неприязненно», «спокойно - настороженно», «терпимо - безразлично» (табл.2).
Таблица 2. В пятибамльной системе оцените Ваше отношение к мигрантам в целом.

\begin{tabular}{|c|c|c|c|}
\hline & Неприязненно & Настороженно & Безразлично \\
\hline 1 & $35 \%$ & $31 \%$ & $29 \%$ \\
\hline 2 & $12 \%$ & $11 \%$ & $10 \%$ \\
\hline 3 & $13 \%$ & $16 \%$ & $17 \%$ \\
\hline 4 & $12 \%$ & $12 \%$ & $13 \%$ \\
\hline 5 & $27 \%$ & $29 \%$ & $31 \%$ \\
\hline & $\begin{array}{c}\text { Доброже- } \\
\text { лательно }\end{array}$ & Спокойно & Терпимо \\
\hline
\end{tabular}

В первой диаде доминирует скорее доброжелательное отношение к мигрантам (35\%), также как во второй (31 \%) и третьей (29 \%). Сказывается, видимо, понимание того, что мигранты являются основными поставщиками рабочей силы, так востребованной в мегаполисе. Живя по меньшей мере в скромных условиях, соглашаясь на работу за более низкую заработную плату, чем коренные жители столицы, они, как ни странно, являются основным источником раздражения населения. 
Некоторая часть столичного населения, возможно, обратив внимание на их количество, особенно на безработных, бродящих по улицам и торговым точкам, вызывающих подозрение в криминальных наклонностях, начинает видеть в них потенциальную опасность.

В то же время позитивное восприятие мигрантов продемонстрировали примерно следующее количество респондентов: доброжелательно (27 \%), спо- койно (29 \%), терпимо (31 \%). Эти данные в целом коррелируются с результатами первого среза.

Столица переполнена мигрантами и не нуждается в дополнительном притоке, - считают $30 \%$ респондентов, но $11 \%$ не согласны с этим тезисом (табл. 3). Более того, мнение, что «мигранты вносят хаос и криминал в столичную жизнь», получило прямо противоположенную квоту: согласен / скорее согласен - $12 \%$ / 20 \%, не согласен/ скорее не согласен - 38 \% / 17 \%.

Таблица 3. На Ваш взгляА, на сколько важны мигранты Аля Аальнейшего развития столицы?

\begin{tabular}{|c|c|c|c|c|}
\hline & $\begin{array}{c}\text { Без мигрантов } \\
\text { невозможно } \\
\text { дальнейшее } \\
\text { развитие столицы }\end{array}$ & $\begin{array}{c}\text { Столице необхо- } \\
\text { димы только } \\
\text { высококлассные } \\
\text { специалисты }\end{array}$ & $\begin{array}{c}\text { Столица перепол- } \\
\text { нена мигрантами } \\
\text { и не нуждается } \\
\text { в дополнительном притоке }\end{array}$ & $\begin{array}{c}\text { Мигранты вносят } \\
\text { хаос и криминал } \\
\text { в столичную жизнь }\end{array}$ \\
\hline Согласен & $30 \%$ & $46 \%$ & $19 \%$ & $12 \%$ \\
\hline Скорее согласен & $18 \%$ & $23 \%$ & $23 \%$ & $20 \%$ \\
\hline $\begin{array}{l}\text { Скорее не } \\
\text { согласен }\end{array}$ & $13 \%$ & $9 \%$ & $19 \%$ & $17 \%$ \\
\hline Не согласен & $28 \%$ & $14 \%$ & $19 \%$ & $38 \%$ \\
\hline $\begin{array}{c}\text { Затрудняюсь } \\
\text { ответить }\end{array}$ & $11 \%$ & $8 \%$ & $20 \%$ & $12 \%$ \\
\hline
\end{tabular}

Мнения, что без мигрантов невозможно дальнейшее развитие столицы, придерживаются $30 \%$ респондентов, в то время как не согласны с ним $28 \%$. Столице необходимы только высококлассные специалисты, считают 46 \% опрошенных горожан. Низкие показатели несогласных по данному критерию показывают, что необходимость привлечения внешней рабочей силы была и остается спорным вопросом. В целом подавляющему большинству респондентов хотелось бы, чтобы на столичном рынке труда работали высококвалифицированные и, конечно же, легальные мигранты, способные передать казахстанцам свой трудовой опыт и передовые технологии.

\section{Обсуждение результатов исследования}

Глобальные тенденции повышения уровня массовости иммиграции в мегаполисах обостряют проблему адаптации мигрантов в местах их компактного проживания. Если мигранты остаются надолго, то возникают еще более сложные проблемы их интеграции (Капицын, 2014).
В Казахстане доля городского населения неуклонно растет, по итогам последней переписи она составляет $54,1 \%$, а сельского - 45,9 \% (Демографический сборник, 2020, с. 113). В ближайшей перспективе дальнейший масштабный поток миграции «село - город» должен привести к соотношению 65/35 \% городского и сельского населения в Казахстане. С развитием высоких технологий закономерно сокращается численность людей, занятых в аграрном секторе, и соответственно возрастает для занятых в сфере услуг и наукоемких производств. Так, Нур-Султан в значительной мере мог бы привлекать образовательную и интеллектуальную иммиграцию, но пока большую долю составляют мигранты с низкой квалификацией.

Главными триггерами миграционных потоков выступают экономический и социальный факторы. В мегаполисе происходит наложение этих процессов в рамках концепции «центр - периферия» и теории глобальных городов С. Сассен (Sassen, 2005). «Центры» создают инновации, притягивая к себе ресурсы «периферии». Концентрация человеческого капитала в лице 
мигрантов усиливает «борьбу за пространственные прибыли» (П. Бурдье), а вместе с ней осложняет криминогенную ситуацию в мегаполисе.

В «каменных джунглях» мегаполиса чрезвычайно сложно в толпе выявить потенциального девианта или опасного преступника. Более того, характерные особенности мегаполиса, отличающие его от других типов поселений, накладывают отпечаток на криминологическую обстановку. Прежде всего речь идет об относительной неустойчивости социальных связей, повышенной мобильности, культурной разнородности и дифференциации населения мегаполиса, специфики его пространственной среды и образа жизни (Segrave, 2019).

Характерными криминологическими показателями миграционной преступности в Нур-Султане являются:

- достаточно невысокий общий уровень преступности (в расчете на 100 тыс. населения);

- общая корыстная и корыстно-насильственная направленность преступности;

- доминирование среди имущественных преступлений квартирных краж и краж автотранспорта;

- резкий рост среди тяжких преступлений доли умышленных убийств;

- относительно невысокий удельный вес молодежной преступности при постоянном ее росте;

- рост групповой и насильственной преступности среди несовершеннолетних (Межнациональные и межконфессиональные отношения в Республике Казахстан (по результатам социологического исследования), 2010).

Современный мегаполис можно описать в терминологии «общества рисков» У. Бека (Бек, 2000), т.к. преступность - один из основных рисков миграционных процессов. Миграционные риски следует понимать как «меру неопределенности, опасности, которые нуждаются в выявлении и минимизировании» (Бородкина и др., 2017, с. 115). Кроме того, наше исследование подтверждает идею Н. Лукмана о «рисках власти», т. к. власть часто опирается на недостоверную информацию при принятии управленческих решений (Luhmann, 1993).

При управлении миграционными процессами следует учитывать несколько групп рисков для самих мигрантов, проявляющихся на микро-, мезо- и макроуровнях социальной реальности. Первая группа - это риски, которым подвергаются сами мигранты; вторая группа касается обществ-доноров, третья группа - это риски принимающего общества. Риск принимающего общества связан с «развитием новых форм социального неравенства, появлением нового низшего класса в лице низкоквалифицированных работников-мигрантов, обладающих ограниченным набором трудовых и социальных прав, и недокументированных мигрантов, лишенных большинства прав», что, в свою очередь, приводит к «развитию этнической стратификации, этнизации социальных проблем и усилению правых антимигрантских позиций как в повестке политических партий, так и со стороны антимигрантских общественных движений» (Бородкина и др., 2017, с. 123, 131). Миграция содержит в себе и ряд других рисков: безопасности (Fabini, 2017), распространения инфекций и антисанитарии (Cui \& Тo, 2020), экономические и культурологические риски (Campos-Delgado, 2020).

\section{Выводы исследования}

Участники мониторинга единодушны с мнением криминологов, что причины и условия миграции и преступности зачастую взаимосвязаны, а потому требуют комплексного анализа с учетом специфики различных видов перемещения и преступной деятельности», и предлагают принимать во внимание указанное взаимовлияние при разработке мер борьбы с преступностью мигрантов (Дядюн, 2012, с. 109-110).

Система предупреждения миграционной преступности должна строиться на минимизации ее рисков. Практическими мерами по минимизации рисков миграционной преступности могут стать: снижение миграционных потоков в столицу за счет приглашения только высококлассных специалистов (так считает $46 \%$ респондентов); ужесточение наказания мигрантов, совершивших преступления (34 \% респондентов), выдворение (депортация) международных мигрантов за пределы Казахстана (61 \% респондентов).

При разработке программ миграционной политики и мер снижения социальной напряженности в столице муниципальным властям города Нур-Султан следует обратить внимание на следующие основные риски миграционной преступности:

- конфликты на бытовой почте между коренным населением и мигрантами;

- коррупционизм и криминализация экономических отношений;

- терроризм и трансграничная преступность.

В целом полученные в ходе социологического исследования данные свидетельствуют, что миграция - как внутренняя, так и внешняя - играет особую роль в развитии межэтнической ситуации в столице Казахстана. Проведенное исследование показывает, что основная масса столичного населения воспринимает мигрантов негативно, хотя внешне и доброжелательно, проявляя к ним толерантность и достаточный уровень общей культуры. Внешние мигранты в межэтническом плане рассматриваются казахами как угроза, в то время как для нетитульных этносов такой угрозой воспринимаются аульные казахи и гастарбайтеры, прибывшие из соседних центрально-азиатских стран. Сказывается стереотипный образ в массовом сознании, связанный с социокультурной несхожестью образа жизни сельских и городских жителей. Негатив со стороны горожан порождает у мигрантов обратный негатив - к горожанам, что в целом усиливает конфликтность данной ситуации. 


\section{Список митературы}

Campos-Delgado, A. (2020). Abnormal bordering: control, punishment and deterrence in Mexico's migrant detention centres. The British Journal of Criminology, 61(2), 476-496. DOI: 10.1093/bjc/azaa071

Cui, K., \& To, S. (2020). Scool Climate, Bystanders' Responses, and Bullying Perpetration in the Context of Rural-to-Urban Migration in China. Deviant Behavior, 1-20. DOI:10.1080/01639625.2020.1752601

Fabini, G. (2017). Managing illegality at the internal border: Governing through "differential inclusion" in Italy. European Journal of Criminology, 14(1), 46-62. DOI: 10.1177/1477370816640138

Kennedy, J. F. (1964). A Nation of Immigrants. New York: Harper \& Row Publishers.

Killias, M., \& Lukash, A. (2019). Migration, not migrants, is the problem: Delinquency among migrants and non-migrants in Switzerland and ex-Yugoslavia. European Journal of Criminology, 17(6), 896-917.DOI: 10.1177/1477370819828329

Luhmann, N. (1993). Risk: A Sociological Theory. Berlin: Walter de Gruyter.

Sassen S. (2005). The Global City: Introducing a Concept. The Brown Journal of World Affairs, 11(2), 27-43.

Segrave, M. (2019). Theorizing sites and strategies of differential inclusion: Unlawful migrant workers in Australia. Theoretical Criminology, 23(2), 194-210. DOI: 10.1177/1362480619827527

Бек, У. (2000). Общество риска: На пути к другому модерну. Москва: Прогресс-Традиция.

Бериев, Г. С., Караева, 3. В. (2019). Криминологический анализ престплений, совершаемых в мегаполисе. Молодой ученый, 20(258), 291-293.

Бородкина, О. И., Соколов, Н. В., Тавровский, А. В. (2017). Социальные риски международной иммиграции в Россию. Экономические и социальные перемены: факты, тендениии, прогноз, 10(3), 114-133. DOI: $10.15838 / \mathrm{esc} / 2017.3 .51 .6$

Дядюн, К. В. (2012). Миграция и преступность: взаимосвязь причин и условий. Гуманитарные исследования в Восточной Сибири и на Дальнем Востоке, 2, 109-114.

Демографический сборник (2020). Нур-Султан: Комитет по статистике МЭ РК.

Капицын, В. М. (2014). Мегаполис: интеграция мигрантов как проблема правового регулирования. Модернизация отечественной системы управления: анализ тенденций и прогноз развития: Материалы Всероссийской научно-практической конференции и ХІІ-ХІІІ Дридзевских чтений (Стр. 383-386). Москва: Институт социологии РАН.

Кобец, П. Н. (2018). Краткая криминологическая характеристика преступности: сборник материалов Международной научно-практической конференции (Стр. 27-29).

Межнациональные и межконфессиональные отношения в Республике Казахстан (по результатам соииологического исследования): Научное издание (2010). Алматы: КИСИ при Президенте РК.

Мь - Казахстан. Анализ положения в области народонаселения в Республике Казахстан (2020). Нур-Султан: ЮНФПА.

Образование в ииффрах. Статистика Евразийского экономического союза (2020). Получено из http://www.eurasiancommission.org/ru/act/integr_i_makroec/dep_stat/econstat/Documents/Education\%20Yearbook/Education EAEU2020.pdf

Щербакова, Е. М. (2018). Мировой демографический барометр. Население и общество, 337-338.

\section{Reference}

Campos-Delgado, A. (2020). Abnormal bordering: control, punishment and deterrence in Mexico's migrant detention centres. The British Journal of Criminology, 61(2), 476-496. DOI: 10.1093/bjc/azaa071

Cui, K., \& To, S. (2020). Scool Climate, Bystanders' Responses, and Bullying Perpetration in the Context of Rural-to-Urban Migration in China. Deviant Behavior, 1-20. DOI:10.1080/01639625.2020.1752601

Fabini, G. (2017). Managing illegality at the internal border: Governing through "differential inclusion" in Italy. European Journal of Criminology, 14(1), 46-62. DOI: 10.1177/1477370816640138

Kennedy, J. F. (1964). A Nation of Immigrants. New York: Harper \& Row Publishers.

Killias, M., \& Lukash, A. (2019). Migration, not migrants, is the problem: Delinquency among migrants and non-migrants in Switzerland and ex-Yugoslavia. European Journal ofCriminology, 17(6), 896-917.DOI: 10.1177/1477370819828329

Luhmann, N. (1993). Risk: A Sociological Theory. Berlin: Walter de Gruyter.

Sassen S. (2005). The Global City: Introducing a Concept. The Brown Journal of World Affairs, 11(2), 27-43.

Segrave, M. (2019). Theorizing sites and strategies of differential inclusion: Unlawful migrant workers in Australia. Theoretical Criminology, 23(2), 194-210. DOI: 10.1177/1362480619827527

Bek, U. (2000). Obshchestvo riska: Na puti k drugomu modernu. Moskow: Progress-Tradiciya. 
Beriev, G. S., Karaeva, Z. V. (2019). Kriminologicheskij analiz prestplenij, sovershaemyh v megapolise. Molodoj uchenyj, 20(258), 291-293.

Borodkina, O. I., Sokolov, N. V., Tavrovskij, A. V. (2017). Social'nye riski mezhdunarodnoj immigracii v Rossiyu. Ekonomicheskie i social'nye peremeny: fakty, tendencii, prognoz, 10(3), 114-133. DOI: 10.15838/esc/2017.3.51.6

Dyadyun, K. V. (2012). Migraciya i prestupnost': vzaimosvyaz' prichin i uslovij. Gumanitarnye issledovaniya $v$ Vostochnoj Sibiri i na Dal'nem Vostoke, 2, 109-114.

Demograficheskij sbornik (2020). Nur-Sultan: Komitet po statistike ME RK.

Kapicyn, V. M. (2014). Megapolis: integraciya migrantov kak problema pravovogo regulirovaniya. Modernizaciya otechestvennoj sistemy upravleniya: analiz tendencij i prognoz razvitiya: Materialy Vserossijskoj nauchno-prakticheskoj konferencii i XII-XIII Dridzevskih chtenij (Str. 383-386). Moskow: Institut sociologii RAN.

Kobec, P. N. (2018). Kratkaya kriminologicheskaya harakteristika prestupnosti: sbornik materialov Mezhdunarodnoj nauchno-prakticheskoj konferencii (Str. 27-29).

Mezhnacional'nye i mezhkonfessional'nye otnosheniya $v$ Respublike Kazahstan (po rezul'tatam sociologicheskogo issledovaniya): Nauchnoe izdanie (2010). Almaty: KISI pri Prezidente RK.

My - Kazahstan. Analiz polozheniya v oblasti narodonaseleniya $v$ Respublike Kazahstan (2020). Nur-Sultan: YUNFPA.

Obrazovanie $v$ cifrah. Statistika Evrazijskogo ekonomicheskogo soyuza (2020). Polucheno iz http://www.eurasiancommission.org/ru/act/integr_i_makroec/dep_stat/econstat/Documents/Education\%20Yearbook/EducationEAEU2020.pdf

Shcherbakova, E. M. (2018). Mirovoj demograficheskij barometr. Naselenie i obshchestvo, 337-338.

\section{Информация об авторе:}

Тесленко Александр Николаевич - доктор педагогических наук, доктор социологических наук, профессор кафедры социально-педагогических дисциплин Кокшетауского университета им. А. Мырзахметова, директор Центра ювенологических исследований, Республика Казахстан, г. Нур-Султан.

\section{About the author:}

Teslenko Alexander Nikolaevich - Doctor of Pedagogical Sciences, Doctor of Sociological Sciences, Professor of the Department of Social and Pedagogical Disciplines, Kokshetau University named after A. Myrzakhmetov, Head of Juvenile Research Center, Republic of Kazakhstan, Nur-Sultan.

Статья поступима в реАакцию 15.08.2021; одобрена после рецензирования 01.10.2021; принята к публикации 29.10.2021.

The article was submitted August 15, 2021; approved after reviewing October 01.2021; accepted for publication October 29, 2021.

Автор заявляет об отсутствии конфликта интересов.

The author declare no conflicts of interests. 